УДК 94(470.63).084.8

Н. Д. Судавцов

\title{
ВОЗРОЖДЕНИЕ СЕЛЬСКОГО ХОЗЯЙСТВА СТАВРОПОЛЬЯ ПОСЛЕ ОСВОБОЖДЕНИЯ ОТ ОККУПАЦИИ В ПЕРИОД ВЕЛИКОЙ ОТЕЧЕСТВЕННОЙ ВОЙНЫ
}

В статье речь идёт о том огромном ущербе, который был нанесён фашистскими захватчиками сельскому хозяйству Ставрополья во время оккупации территории аграрного края. Оккупанты грабили колхозы, совхозы, машино - тракторные станции, население. Из края вывозились новейшая техника, оборудование, сельскохозяйственная продукция. В статье показаны пути, формы и методы восстановления сельского хозяйства в крае тружениками села. Также идёт речь о той помощи, которую оказали Ставрополью в возрождении жизни государство, другие республики и области СССР, шефстве над краем Азербайджанской ССР и Чкаловской области. Большое внимание уделено помощи горожан в проведении сельскохозяйственных работ, обеспечении МТС, колхозов, совхозов запасными частями для ремонта тракторов, комбайнов, сельскохозяйственной техники, которые выпускали предприятия, артели промысловой кооперации. Работая под лозунгом «Всё для фронта! Всё для победы!», участвуя в социалистическом соревновании, женщины, подростки, старики не только возрождали жизнь в крае, но и своим самоотвер- женным трудом, надрываясь от непосильного труда, не доедая, не досыпая, делали всё для того, чтобы обеспечить действующую армию и страну всем необходимым. В связи с тем, что техника была разбита, изношена, многие работы приходилось выполнять вручную, используя живое тягло и прикладывая огромные физические усилия. И делалось это в условиях, когда часто не хватало самого необходимого для повседневности сельского населения Ставрополья в условиях тяжёлой войны. Результатом самоотверженного труда, огромных усилий людей, подкреплённых помощью государства и других регионов страны, после освобождения от оккупации многое было сделано по возрождению сельскохозяйственного производства, восстановлению посевных площадей, поголовья животноводства, предприятий, артелей промысловой кооперации, перерабатывающих сельскохозяйственное сырьё, а также выпускающих для населения предметы первой необходимости.

Ключевые слова: Великая Отечественная война, оккупация, разрушения, ущерб, восстановление, соревнование, шефство, молодёжь, колхозы, МТС.

N. Sudavtsov

\section{THE REVIVAL OF AGRICULTURE OF STAVROPOL REGION AFTER LIBERATION} FROM OCCUPATION IN THE PERIOD OF THE GREAT PATRIOTIC WAR

The article deals with the enormous damage that was inflicted by the fascist aggressors on the agriculture of Stavropol region during the occupation of the territory of the agrarian region. The invaders robbed collective farms, state farms, machine-tractor stations, population. The latest technology, equipment and agricultural products were exported from the region. The article shows the ways, forms and methods of restoring agriculture in the region by village workers. It also deals with the assistance that the Stavropol government rendered to the revival of life of the state, other republics and regions of the USSR, and patronage over the territory of the Azerbaijan SSR and the Chkalov region. Much attention is paid to the assistance of citizens in carrying out agricultural work, providing motor-tractor stations (MTS), collective farms, state farms with spare parts to repair tractors, combines, agricultural machinery, which were produced by enterprises, artels of commercial cooperation. Working under the slogan "Everything is for the front! Everything for victory!" and participating in socialist compe- tition, women, teenagers, old people not only revived life in the province, but also by their selfless work, straining from overwork, with lack of food and sleep, they did everything to ensure the current army and country with everything they needed. As the equipment was broken, worn out, a lot of work was done manually, using living matter and applying tremendous physical effort. And this was done under conditions when the Stavropol population in conditions of a hard war was in need of goods for everyday life.

After the liberation from occupation, much work was done to revive agricultural production, restore agricultural areas, livestock, enterprises, cooperatives processing agricultural raw materials, as well as producing goods for the population. It was the result of selfless labor, tremendous efforts of people supported by the state and other regions of the country.

Key words: World War II, occupation, destruction, damage, restoration, competition, patronage, youth, collective farms, MTS.
На Ставрополье, освобождённом от оккупации, шла невиданная в истории созидательная работа по возрождению экономики, культуры, социальной сферы, разрушенной фашистами. Проходила 
она в очень трудных военных условиях. Немецко-фашистские оккупанты, выполняя указания А. Гитлера, стремились оставить после себя на покидаемых территориях зону «выжженной» земли, нанося им максимальный ущерб.

О возрождении сельского хозяйства Ставрополья в годы Великой Отечественной войны написано не так уж много. Но тема настолько обширна и многогранна, требует более пристального внимания, глубокого изучения и осмысления процессов, проходивших в аграрном Ставрополье в условиях великой войны и роли в этом человеческого фрактора.

На территории края оккупанты пробыли около полугода с августа 1942 по январь 1943 г. Но и за это время краю был нанесён огромный ущерб в 14,6 млрд рублей в ценах того времени. Поскольку Ставрополье было краем аграрным, то основной ущерб приходился на сельское хозяйство за счёт которого кормились оккупационные войска, а в Германию вывозились продовольствие, сырьё. В первую очередь шло разграбление колхозов и совхозов, которые были сохранены как общины и госхозы. Была уничтожена птица, значительная часть крупного рогатого скота, овец, разрушены животноводческие помещения и т.д. Ущерб сельскому хозяйству края составил 11 млрд рублей. Многие учреждения культуры школы были превращены в казармы, конюшни, подсобные помещения и пр. Невосполнимой потерей было уничтожение более 33 тыс. человек. Людей использовали на строительстве военных объектов, укреплений и других тяжёлых работах $[23$, c. 115,116$]$.

Существенно была подорвана материально-техническая база сельского хозяйства - основа его устойчивой работы. Было уничтожено более 4,5 тысяч тракторов, полторы тысячи комбайнов, свыше 8 тыс. плугов, лущильников, 4037 жаток, 714 молотилок и т.д. Были уничтожены 164 ремонтных мастерских, частично повреждено 209 мастерских в колхозах и совхозах, в Германию было вывезено или выведено из строя 1885 металлорежущих станков, 532 электромотора и нефтедвигателя. В колхозах разрушено 268 клубов и красных уголков, 47 детских садов, 15 детских яслей и т.д. [23, с. 116]. В этом проявилась политика германского фрашизма: грабить, уничтожать и убивать.

В результате разграбления народного богатства в сравнении с 1 июля 1942 г. в крае осталось $37 \%$ лошадей, $27 \%$ крупного рогатого скота в том числе $20 \%$ коров, 25,2 \% овец и коз, $15 \%$ свиноматок, $6 \%$ птицы. В ряде районов потери были более значительными. В Курском районе из 52299 овец осталось только 1502 головы или 3\% в Георгиевском районе из 3901 головы крупного рогатого скоты - 247 голов, около $6 \%$, в Спицевском районе из 4141 свиней осталось 183 или $4 \%$ и т.д. $[14$, л. 107,116$]$.

Несомненно, ущерб был бы значительно больше, если бы не поражение фашистов под Сталинградом, стремительное наступление Красной
Армии на Северном Кавказе, которая в январе 1943 г. полностью изгнала врага с территории края, а также самоотверженность советских людей, которые, рискуя жизнью, спасали народное достояние.

Всё это нужно было как можно быстрее восстановить, несмотря на то, что шла война и основные средства, усилия государства, населения направлялись на борьбу с врагом. Сразу же после освобождения колхозники сводили в хозяйства частично разобранный накануне оккупации скот, сносили упряжь, доставали припрятанные узлы и механизмы, подбирали брошенных в поле лошадей, скот и т.д. Было создано 1500 бригад по сбору техники, запасных частей для её ремонта Одновременно разбирались развалины, восстанавливались разрушенные постройки, мастерские, жильё, школы, больницы. Готовясь к весенне-полевым работам, собирали для посева зерно из личных запасов

Большую помощь Ставрополью с первых дней освобождения оказали государство, трудящиеся республик и областей страны. 23 января 1943 г. ЦК ВКП(б) и СНК СССР приняли постановление «О мерах по восстановлению МТС и колхозов в районах, освобождённых от немецко-фашистских оккупантов», определившим программу деятельности по восстановлению экономики, социальной сферы, оказанию помощи на селе. Наркоматам совхозов, обороны, ВМФ, среднего машиностроения поручалось выделить пострадавшим районам тракторы, комбайны, сельскохозяйственный инвентарь, автомобили, запасные части. Предусматривалась мобилизация и направление в освобождённые районы кадров для работы, в том числе эвакуированных из освобождённых районов [22, с. 90-94]

Исходя из постановления, ЦК компартий и правительства республик приняли постановления, в которых определили своё участие этих регионов в восстановлении Ставропольского края. СНК и ЦК компартии Казахстана 27 января 1943 г решили отгрузить Ставрополью 100 автомашин, направить 25 механиков, 15 директоров МТС, 25 агрономов, 8 заведующих райзо, 5 бухгалтеров [20, л. 163, 164]. Решениам ЦК компартии и СНК Киргизии на Ставрополье было направлено 5 директоров МТС 21 механик, 25 трактористов, 10 агрономов [21, л. 98]. Из Узбекской ССР в феврале 1943 г. было отправлено на Ставрополье 1000 тракторов, столько же плугов, 600 сеялок, более 1100 работников сельского хозяйства. [19, л. 233, 234].

К началу сева 1943 г. МТС и совхозы получили 5800 тракторов, комбайнов, автомашин. В хозяйства прибыли 4385 трактористов, комбайнеров, бригадиров. Колхозы и совхозы получили на проведение сева более 2 миллионов пудов семян и свыше 50 тысяч голов реэвакуированного скота. Были предоставлены льготы по поставкам продуктов государству. Колхозники Азербайджана выделили из личных хозяйств 4200 голов крупного рогатого скота, наркомзем республики отправил сельхозмашин на 271 тыс. рублей, на 100 тыс. рублей запасных частей [2, с. 280, 281]. 
За счет их завоза мощность тракторного парка в МТС возросла на 20 процентов. Прибывшие в 1943 г. в Ставропольский край работники трудились хорошо. Так, в Султановской МТС Курсавского района наивысшую выработку на тракторе СТЗ дала Раиса Боборыкина, прибывшая в край из Чкаловской области. Она на колёсном тракторе за смену пахала по 5 с лишним гектаров [29].

Весенне-полевые работы в 1943 г. начинались в очень сложных условиях. Несмотря на большую помощь государства, республик и областей в колхозах, совхозах, МТС ощущалась острая нехватка тракторов, живого тягла. Хотя многое было собрано и реставрировано из сельскохозяйственных орудий, тем не менее, отсутствие новых запасных частей, тракторов сказывалось на уровне работы техники. В большинстве МТС не было механических мастерских. Даже к концу 1943 г. их не было в 51 МТС, что сказывалось на качестве ремонта. Не случайно, почти четверть тракторов не работала, а многие простаивали в борозде. Поэтому главная тяжесть проведения весенне-полевых работ 1943 г. легла на живое тягло. А если учесть, что в результате саботажа сельскохозяйственных работ осенью 1942 г. почти ничего не было вспахано под весенний сев и засеяно озимых всего 462 тыс. га на низком агротехническом уровне, то весной 1943 г. ставилась задача наверстать и посеять не менее 930 тысяч га яровых. Исходя из складывающейся обстановки в районах, многое сделали, чтобы лучше подготовиться к весенне - полевым работам. Колхозники, рабочие совхозов собрали для сева около двух с половиной миллионов пудов зерна из собственных запасов [4, л. 80].

Несмотря на трудности, многие механизаторы неплохо подготовились к полевым работам. В колхозе «Оборона страны» Нагутского района женская тракторная бригада, И. Крахмаля, взвесив свои возможности, взяла на 1943 г. высокие обязательства - выработать на 15-сильный трактор не менее 1000 гектаров мягкой пахоты, высококачественно провести все работы, сэкономить не менее $10 \%$ топлива и горючесмазочных материалов, $15 \%$ запасных частей против нормы [11]. Они обратились ко всем трактористкам края с призывом продолжить социалистическое соревнование женских тракторных бригад. Трактористки, в частности, писали о том, что мало быть благодарными советским воинам за освобождение от фашистов: «Мы должны сделать всё, чтобы обеспечить Красною Армию всем необходимым для дальнейшего успешного наступления на Запад, где советских воинов ждут миллионы наших братьев и сестер. Мы должны дать фронту и стране столько хлеба, мяса и других сельскохозяйственных продуктов, сколько это требуется для окончательного разгрома подлых фашистов. Трудно будет нынче, но надо справиться со своей задачей. На нашу долю, дорогие подруги, ложится в значительной мере выполнение этой задачи потому что в нынешнем году большинство водителей стальных коней, -мы женщины: каждый наш трактор должен работать за двоих троих» [26].
Несмотря на самоотверженный труд механизаторов, тракторный парк края весной 1943 г. работал плохо. Свидетельством тому было то, что к 1 мая тракторами вспахали 250 тыс. гектаров условной пахоты из намечавшихся 600 тыс. гектаров [27]. Значительная часть тракторов простаивала. В Александровской МТС на 15-сильный трактор было выполнено лишь 2,7 га при норме 8,3 га в сутки. Такое же положения сложилось в Саблинской, Преградненской, Донской и других МТС.

Весной 1943 г. значительно возросла роль живого тягла в сельскохозяйственных работах. В постановлении СНК СССР и ЦК ВКП(б) «О государственном плане развития сельского хозяйства на 1943 год" для колхозов и совхозов Ставропольского края была установлена выработка на весенне-полевых работах на рабочую лошадь или пару волов 10 га мягкой пахоты. Предусматривалось привлечение на полевые и транспортные работы малопродуктивных коров. Это в тот период было оправдано, так как без максимального использования живого тягла невозможно было провести весенне-полевые работы. Тем более, если учесть, что в период оккупации не была вспахана зябь. Но при этом, многие семьи были обречены на полуголодное существование, поскольку коровы, работавшие в упряжи, переставали давать молоко, которое для многих семей было единственным источником питания.

В то время бытовало выражение «Что для коня честь, то для трактора укор». И это имело основания. Во многих МТС выработка на 15-сильный трактор была даже ниже, чем у хорошо работающих пахарей. В передовом Петровском районе к середине мая на 15-сильный трактор выработали в среднем по 70 га. В то же время передовики, ежедневно выполняя на пахоте две-три нормы, вспахали по 60-70 гектаров на упряжку. В колхозе им. Сараева это составило в среднем 63 гектара на упряжку [16].

В хозяйствах изыскивались внутренние резервы и возможности для успешного проведения всех сельскохозяйственных работ. Важную роль в этом играли комсомольские организации, которые мобилизовали молодёжь на ударный труд. В годы войны подавляющее большинство колхозов не имели организаций ВКП(б). В соответствии с уставом ВКП(б), принятом на 18-м съезде партии, на комсомольские организации возлагалась ответственность за положение дел в хозяйствах. Многие из них выступили застрельщиками организации восстановительных работ. Примером может быть Егорлыкский райком комсомола, который глубоко вникал в дела колхозов, предметно рассматривая вопросы сельскохозяйственного производства на бюро РК ВЛКСМ. За 1943-1944 гг на бюро были заслушаны доклады и информации о положении дел 11 председателей колхозов, 3 директоров МТС, 11 бригадиров полеводческих и тракторных бригад. Особое внимание уделялось участию комсомольцев и молодёжи в делах хозяйств, воспитательной работе [5, л. 65].

Комсомольцы и молодёжь колхоза «Парижская коммуна» Буденновского района сразу по- 
сле освобождения приступили к восстановлению колхоза и многое сделали по подготовке к весенне-полевым работам. Они собрали рабочий скот семена для посева, подготовили сельхозинвентарь. Это позволило колхозу выступить инициатором социалистического соревнования в районе за высококачественное проведение работ. Они взяли повышенные обязательства: добиться быстрейшего сбора семенного фонда, обеспечить весенний сев высококачественными семенами организовать образцовый уход за живым тяглом в период подготовки и проведения весеннего сева; систематически перевыполнять производственные нормы, выполнять работу только с высоким качеством, подчинив её лозунгу: «Всё для фрронта! Всё для победы над врагом!»; добиться быстрейшего сбора средств на строительство танковой колонны «Ставропольский колхозник» и бронепоезда «Комсомолец Ставрополья»; регулярно проводить среди колхозников читки газет и беседы, выпускать стенные газеты, один раз в месяц проводить вечера самодеятельности; вызвали на соревнование колхоз «Сталинская конституция» [1]. Взяв после освобождения высокие темпы в работе, они добились замечательных результатов и завоевали по итогам работы в 1943 г переходящее красное знамя ЦК ВЛКСМ. Но в целом, на наш взляд, организаторская роль комсомольских организаций колхозов по-настоящему ещё не оценена

Весной 1943 г. особо ярко в проведении сельскохозяйственных работ проявился вклад подростков, о которых женщины говорили с гордостью и грустью «Наши мужички». По инициативе комсомольцев и молодежи колхоза им. Молотова Изобильненского района, одобренной крайкомом ВЛКСМ, широко развернулось соревнование молодых пахарей на живем тягле [3, л. 160-161] Крайком комсомола и краевой земельный отдел организовали боевое соревнование молодых пахарей, которых вышло на поля края более 10 тысяч человек. Для победителей были учреждены переходящее красные знамёна, вымпелы, фрлажки, премии, которые в хозяйствах, бригадах вручались ежемесячно, еженедельно, ежедневно. Весной край выполнил план весеннего сева Было посеяно 1311 тыс. га. [11, л. 21].

Важное значение для края имело постановление СНК СССР от 7 мая 1943 г. «О первоочередных мероприятиях по восстановлению хозяйства Ставропольского края, разрушенного немецкими оккупантами», которым определялась большая помощь на восстановительные работы - ассигновывалось 77056 тысяч рублей, выделялись материальные фонды, определялись сроки ввода в строй предприятий, жилья, социально-культурных учреждений. Было выделено 10 млн рублей долгосрочного кредита колхозам на восстановление построек, приобретение инвентаря, 3 млн рублей на восстановление жилого фонда, находящегося в личном пользовании, 2 млн рублей колхозникам на обзаведение скотом и восстановление построек. Всего же для края выделялось 102 млн рублей. [13, л. 130-131].
Дпя восстановления МТС, пятигорского мотороремонтного завода и организаций системы наркомзема СССР были ассигнованы 4 млн рублей, для совхозов 2 млн рублей, на борьбу с вредителями сельского хозяйства 1,6 млн рублей и выделены химикаты. На покупку и контрактацию скота для укомплектования животноводческих ферм выделялось 4 млн рублей на восстановление разрушенных сооружений по обводнительным и оросительным системам - 7,1 млн рублей [14, л. 135-136]

После принятия 21 августа 1943 г. постановления ЦК ВКП(б) и СНК СССР «О неотложных мерах по восстановлению хозяйства в районах освобождённых от немецкой оккупации", содержавшем комплексную программу возрождения районов, подвергшихся оккупации, над Ставропольским краем взяли шефство Азербайджанская ССР и Чкаловская область, которые оказали существенную помощь в материально-техническом обеспечении сельского края [17, с. 65-104].

В целом же 1943 г. для Ставрополья в сельском хозяйстве сложился очень тяжело. К тому колоссальному ущербу, который был нанесен оккупантами, добавилась засуха. Озимые, посеянные осенью 1942 г. в период оккупации на низком агротехническом уровне, некондиционными семенами, в сухую землю, практически не взошли. Всходы стали появляться только весной. Но и здесь им не удалось набрать силы в связи с малоснежной зимой и продолжительной весенней засухой.

В связи с затянувшимся весенним севом хлеба в своём развитии запоздали против обычных сроков на 15-20 дней и их созревание попало в июле-августе под губительное влияние восточных суховеев. Это привело к резкому снижению урожайности, против тех предварительных оценок, которые делались на первое июля. В итоге и без того низкая урожайность оказалась ещё ниже в 2-3 раза. Во многих районах не получили даже того количества зерна с гектара, которое необходимо для засева гектара. В Благодарненском районе урожайность озимых была 1,1 центнера с га, Новоселецком - 1,4 ц, Левокумском - 0,9, Туркменском, Бурлацком - 1,5 ц, Арзгирском, Буденновском, Черкесской $\mathrm{AO}-1,8$ ц с гектара и т.д. Урожайность яровых в подавляющей части районов была 1,5-2 ц с гектара. И только в более благоприятных Александрийско-Обильненском, Георгиевском, Либнехтовском, Минераловодском, Нагутском районах она была 9 - 11 ц с гектара. [8, л. 24-25] По краю средняя урожайность колосовых составила 3,5 ц с гектара, в том числе озимых 2 ц, проса 2,5 ц, кукурузы 8 ц. Край оказался в тяжелейшем положении с обеспечением хлебом. Зерновых в 1943г. собрали в четыре раза меньше, чем в 1940 г. [24, с. 52] На тяжёлое продовольственное положение на Ставрополье поВлияло и то, что по постановлению СНК СССР и ЦК ВКП(б) от 22 февраля 1943 г. край должен был сдать в фонд Красной Армии к маю 10 млн пудов зерна из урожая 1942 г. [7, л. 164] 
Решения о сдаче хлеба из урожая 1942 г. было не случайным. Летом 1942 г. при хорошем урожае в июле-августе было скошено значительное количество зерновых жатками, вручную, который был уложен в скирды с расчетом, что будет обмолочен осенью и зимой. Но в период оккупации фашистским властям так и не удалось должным образом наладить сельскохозяйственные работы, в том числе и обмолот хлебов. Поэтому в крае остались неубранными, а также не обмолоченными сотни тысяч гектаров сельскохозяйственных культур. К примеру, в Новоселецком районе имелось в скирдах не обмолоченного хлеба с 2440 га, 330 га неубранной кукурузы. [14, л. 150] Аналогичное положение было во многих районах края. Поэтому с первых же дней после освобождения труженики села приступили к их обмолоту и сдаче хлеба государству. Краю было доведено задание по сдаче в фонд Красной Армии 10 миллионов пудов зерна.

Поскольку зерна не хватало для выполнения задания, оно изымалось не только в хозяйствах, но и непосредственно у колхозников, что значительно снижало их хлебные запасы. Всего к маю 1943 г. было сдано в фонд Красной Армии 5 миллионов пудов зерна.

По визуальным прогнозам, урожая на 1 июля 1943 г. определили, что в крае будет собрано 6265 млн пудов зерна, поэтому план сдачи его государству установили 23,4 млн пудов. Но засуха и суховеи в июле - августе практически уничтожила урожай на большей части края. Казалось бы, руководство края должно было забить тревогу сразу, как только стало ясно, что план хлебосдачи не будет выполнен. Но этого своевременно не сделали. Несмотря на нажим край хлебопоставки к октябрю выполнил на $26 \%$ [8, л. 28].

Исходя из создавшегося положения, крайком ВКП(б) и крайисполком в октябре 1943 г обратились в СНК СССР с запиской, в которой сообщалось о тяжёлом положении дел крае и высказывалась просьба об уменьшении плана хлебозаготовок, на половину в фонд Красной Армии на 9 млн пудов [8, л. 27]. Однако, план изменен не был.

Между тем положение усугублялось. Нажим по сдаче хлеба не привел к выполнению плановых заданий. К концу 1943 г. выполнение составило 55,4 \%, в том числе в фонд Красной Армии на $47 \%$ от плана. На озимый сев было израсходовано 5,4 млн пудов и засыпано семян яровых 1,9 млн пудов, треть потребности $[8, \pi .145,147]$.

В крае резко обострилась продовольственная проблема, которая касалась, прежде всего, колхозников, особенно в хозяйствах, наиболее пострадавших от оккупации. И прежде всего северных и северо-восточных районов края, подвергшихся жестокой засухе, особенно Апансенковского, Арзгирского, Благодарненското, Бурлацкого, Левокумского, Навоселецкого, Петровского, Туркменского и других. Конечно, продовольственное положение было тяжелым для всех жителей края. Но если рабочие, служащие, интеллигенция получали по карточкам пусть и небольшую, но гарантированную норму, а также заработную плату, то колхозники часто не получали ничего. В части хозяйств они получили только аванс по итогам работы в первом полугодии всего по 30-100 граммов на трудодень, а во многих районах вообще ничего не получили [8, л. 148]. Трудности усугублялись ослаблением личного подсобного хозяйства колхозников, где в результате засухи погибли значительные площади посевов овощей и картофеля на приусадебных участках.

В записке крайкома ВКП(б) и крайисполкома И. В. Сталину в январе 1944 г. отмечалось, что значительная часть колхозников оказалась в исключительно тяжёлом положении и нуждается в немедленной продовольственной помощи. В ряде районов имелись случаи опухания от истощения, отсутствия хлеба, продуктов питания учащаются случаи убоя скота, самовольного выезда за пределы края в Апанасенковском, Бладагодарненском, Ипатовском, Коясулинском и других районах. К концу 1943 г. по неполным данным из Благодарненского района выехало 2357 семей, из Каясулинского 700 семей и т.д. [25, с. 180].

В поисках выхода из создавшегося положения, многие семьи, особенно многодетные, переселялись на территории Карачаевской АO, ЧеченоИнгушской АССР, откуда были депортированы ингуши, карачаевцы, чеченцы и где предоставлялись льготы, оказывалась помощь продовольствием, в обзаведении хозяйством. Хотя многим переселение было не по душе, они видели в этом возможность спасти детей и себя от голода.

Крайком ВКП(б) и крайисполком снова просили уменьшить хлебопоставки и оказать краю помощь продовольствием. Однако помощи оказано не было. В тоже время обстановка с продовольствием обострялась. Так, в Шпаковском районе в 17 колхозах из 30 в феврале 1944 г. не было никаких продуктов. В районе было 22700 иждивенцев. Положение усугубилось ещё и тем, что 3 сентября в районе прошли сильный град и ливень, которые уничтожили все огородные культуры [12, л. 97]. В Петровском районе на 1 марта 1944 г. было 2 тысячи остронуждающихся семей, которым нужно было оказать немедленную помощь. Среди них было более 100 семей, опухших от голода. В пищу употреблялось все. Появились случаи смертельного отравления абрикосовыми косточками. Большинство из остро нуждающихся составили члены семей фронтовиков. Кроме того это были многодетные семьи, а также эвакуированные, которые не имели личных хозяйств. Из-за того, что не во что было одеться и обуться многие дети этих семей не ходили в школу, где в это время выдавали горячие завтраки, на которые в крае специально выделялась 350 тонн муки в месяц. Из неё в школьных столовых готовилась еда, что во многом зависело от мастерства и фантазии поваров [7, л. 158]

Из-за отсутствия керосина в домах было скудное освещение. Поскольку почти не было спичек, то в ходу было кресало, поочерёдное сохранение огня жильцами улиц. Тяжелейшее положение было с лекарствами. Из-за недоедания, низкого 
уровня лечения значительно увеличилась смертность населения. В 1943 г. она превысила рождаемость, в том числе среди новорождённых почти в два раза [18, с. 256-257].

Крайком ВКП(б) и крайисполком изыскивали возможности оказания помощи населению. Было решено провести перераспределение хлебных ресурсов в крае между районами, в которых был более высокий урожай и теми, где была засуха. Так 4 марта 1944 г. решением крайисполкома была оказана помощь Петровскому району 1500 пудов и Шпаковскому району 600 пудов зерна из благополучного Либкнехтовского района [12, с. 97].

Но этого было крайне мало. Учитывая просьбу краевых властей правительство СССР на период весенне-полевых работ выделило краю ... для организации питания на сельхозработах. Из Чкаловской области к 1944 году прибыло два эшелона, в которых было 63 металлорежущих станка, 40 разных моторов, 18 тыс. различных инструментов, 2 дизеля, из Азербайджана эшелонами доставили 250 т цемента, 100 т. мазута, 5 тыс. м² стекла, 2 тыс. штук посуды и т.д. [11, л. 20]. Для осеннего сева 1943 г. правительство СССР выделило Ставропольскому краю 200 тыс. центнеров семенного зерна [11, л.15].

В 1943 г. в целом сельские труженики края провели колоссальную работу. К началу 1944 г. функционировали все колхозы, совхозы, МТС, около 5 тысяч животноводческих ферм, в том числе 1350 крупного рогатого скота, 1284 овцетоварных 983 свинотоварных, 756 птицетоварных и т.д. Были восстановлены школы, больницы, фельдшерские пункты амбулаторные учреждения и др. [9, л. 105].

И это в условиях, когда шло значительное отвлечение рабочей силы из села: на строительство военных объектов на территории края, мобилизации на военные заводы, восстановительные работы в Донбассе, Сталинграде и других местах, ремесленные училища и школы $Ф 30$, в вооружённые силы, возвращения эвакуированных в родные места. Таким образом, 1943 год, будучи самым трудным для ставропольцев в годы войны, оказался решающим в возрождении жизни крае после освобождения от оккупации.

Большое значение имело постановление СНК СССР 27 января 1944 г. «О мерах по дальнейшему развитию сельского хозяйства Ставропольского края», в котором ставилась задача в ближайшие два-три года завершить восстановление сельского хозяйства и достичь довоенного уровня. Краю предусматривалось оказание помощи техникой, запасными частями, финансами [2 c. 286]. На Ставрополье стали поступать запасные части, тракторы. Восстановливаясь, предприятия максимально наращивали производство продукции для сельского хозяйства. Так, Черкесский завод «Молот» освоил белее десяти видов деталей к тракторам и сельскохозяйственным машинам. Предприятиям были доведены планы по производству запасных частей. Хотя это до конца и не решало стоящих проблем, но существенно укрепляло материально-техническую базу сельского хозяйства края.

Зима 1943-1944 гг. радовала сельских тружеников. Была она снежной, озимые вступили в зиму в хорошем состоянии. Колхозники настойчиво изыскивали возможности для хорошей подготовки к работам в 1944 г. Пример подавали передовые хозяйства.

Труженики колхоза им. Володарского Новоалександровского района, обсуждая 5 января 1944 г., как лучше провести сельхозработы, решили восстановить хозяйство на довоенном уровне, провести сев за 10 рабочих дней и получить 100 пудов зерновых с гектара. Это базировалось на расчетах, опыте восстановительных работ, приобретенном в 1943 г. Оккупанты привели в негодность часть сельхозинвентаря, разграбили фермы. Зябь осенью 1942 г. не поднималась. После освобождения колхозники собрали и восстановили сельхозтехнику, собрали 50 лошадей, 20 волов, свели на фермы 247 голов крупного рогатого скота, 326 овец, 500 голов птицы. Работали, не покладая рук, от мала до велика. И.Г. Кретов вспахал весной на лошадях 65 гектаров, выполняя задания на 140-150\%, П. В. Трубицин 50 га на волах. Весной посеяли 870 га зерновых и 324 га технических культур, что было значительно больше плана. Слово володарцы сдержали. Урожай получили хотя и ниже, чем до войны, но неплохой, что позволило колхозу рассчитаться с государством и сдать 47 тыс. пудов зерна, на $160 \%$ выполнить поставки по мясу. Осенью посеяли более 900 га озимых. В колхозе было 418 трудоспособных и подростков, а работало 579 человек, в их числе старики, инвалиды, заработавшие в среднем по 198 трудодней, каждый подросток 163 трудодня, старики старше 60 лет по 317 трудодней [33]. Подсчитав возможности, они призвали тружеников села страны последовать их примеру [36].

При подготовке к уборке урожая 1944 Г. краевые власти неоднократно обращались в ЦК ВКП(б) и СНК СССР с просьбами помочь решить вопросы технического обеспечения, поскольку на месте решить это было невозможно. На 20 мая 1944 г. в крае было отремонтировано всего 509 комбайнов из 3413, из которых 1200 не имели двигателей, $30 \%$ хедеров - приводных ремней. Комбайны, восстановленные в 1943 г. от длительной работы на косовице, обмолоте зерна, требовали для ремонта запасных частей. Между тем в 4-м квартале 1943 года, а также в 1-2 кварталах 1944 года в край для ремонта моторов было завезено запасных частей всего на 18 тыс. рублей Совсем не поступали моторы, приводные ремни, подшипники и др. В мастерских МТС план реставрации деталей, поддающихся восстановлению в условиях МТС, был выполнен на $75 \%$ большинство методом электросварки. В мастерских МТС план реставрации деталей, поддающихся восстановлению в условиях МТС, был выполнен на 75 \% большинство методом электросварки. Всего планировалось включить в уборку 2000 комбайнов, которыми скосить 550 тыс. гектаров, а остальное 
косилками, вручную. Половина гусеничных тракторов не участвовала в сельхозработах, 1053 не были отремонтированы [11, л. 197-199].

В крае была проведена огромная организаторская работа по подготовке к уборке 1944 г. В хозяйствах, на районных, краевом предуборочных совещаниях скрупулёзно рассматривалась готовность к битве за урожай, брались повышенные обязательства. Механизатор Привольненской МТС 3. И. Мухамедиев в газете в мае 1944 г. писал: «В 1943 году с группой трактористов я прибыл в Ставропольский край. Башкирский народ, пославший меня, дал наказ - работать, не жалея сил на восстановлении колхозов, разрушенных немецкими оккупантами. И я свято выполняю наказ своего народа. Несмотря на то, что в прошлом году мне вручили комбайн «Сталинец» уже в самый разгар уборки, я сумел убрать 450 га и сохранить машину в хорошем состоянии. Выезжая на краевое совещание комбайнеров, я дал своим товарищам по работе обязательство - убрать в текущем году своим комбайном 1000 га. Уверен, что не только выполню, но и перевыполню свое обязательство. Братья-воины Красной армии, Родина будут довольны моей работой» [32]

Поскольку в крае остро ощущалась нехватка техники и живого тягла для выполнения сельскохозяйственных работ, то широко использовались коровы. Чтобы в какой-то мере компенсировать потери колхозников от этого, руководство края обратилось в правительство с просьбой разрешить колхозам выдавать в 1944 г. колхозникам, работающим на своих коровах на подъеме зяби, дополнительно натурой 18 кг за гектар пахоты. СНК СССР 4 октября 1944 г. поддержал предложение руководства края и разрешил производить оплату за счет $15 \%$ отчислений от фактической сдачи зерна на заготпункты [10, л. 47]. Конечно, оплата была не такой уж большой, но она в какой-то мере компенсировала потери семьям от использования коров на работах.

Важную роль сыграло переключение Пятигорского мотороремонтного завода с военных заказов на выпуск продукции для сельского хозяйства. На Ставрополье был выдвинут лозунг «На каждом станке ежедневно изготавливать запасные части для сельского хозяйства». Поддерживая его, коллектив завода «Красный металлист» в ноябре 1944 г. взял шефство над Кевсалинской, Книгинской, Софиевской МТС Ипатовского района. Заводчане решили отремонтировать для MTC края 10 металлорежущих станков, выполнить план по изготовлению запасных частей к тракторам не менее чем на $130 \%$, освоить производство десяти новых видов запасных частей, не менее раза в месяц направлять в подшефные MTC бригады для оказания помощи в ремонте. В обращении коллектива к работникам промышленности и транспорта края содержался призыв: «Заказ деревне - заказ фронту. Все силы на помощь сельскому хозяйству!» [30]

Этот призыв нашел горячий отклик в трудовых коллективах предприятий и организаций края. На собрании партийного, советского, хозяйственно- го актива, стахановцев г. Пятигорска, совместно с представителями подшефных МТC 5 декабря 1944 г. отмечалось, что 31 предприятие города изготовили разных запчастей к тракторам и сельхозмашинам на 5 млн рублей. В то же время подчеркивалось, что «в новую ремонтную компанию нужно работать во много раз лучше, чтобы привести тракторный парк и машины МТС в «полную боевую готовность». Представители трудовых коллективов на собрании брали конкретные обязательства. Стахановец мотороремонтного завода фрезеровщик Лютин обязался изготовить в декабре сверх плана 180 остродефицитных деталей к тракторам. Мастер Школьников заявил, что механический цех изготовит в декабре 8 тыс. пальцев и поршней, реставрирует гильзы для 350 тракторов. Выступавшие рассказали об активной медицинской, культурно-просветительной помощи коллективам МTC.

Опираясь на помощь горожан, коллективы MTC широко развивали товарищескую взаимопомощь. Так, коллектив Богословской МТС, выработав на 15-сильный трактор 577 га мягкой пахоты, к 10 ноября 1944 г. выполнилгодовой плантракторных работ на 119 \%. Образцы героического труда показали передовики соревнования молодёжные тракторные бригады М. Плотникова, выработавшей на колесный трактор 1026 га мягкой пахоты и занявшей первое место в МТС, соревнующаяся с ней женская бригада И. С. Мозгового, выработавшая на трактор 810 га, заняла второе место. В MTC говорили: «Как танки в бой ведут гвардейцы фронта, так водили свои машины на колхозных полях трактористы Василий Гедаш, Алексей Маляренко, Мария Коломейцева, Лаврентий Белоцерковец» $[6$, л. 140]

Эти успехи дали коллективу МТС уверенность в своих силах и выступить инициатором краевого соревнования на осенне-зимнем ремонте: «Вера в скорую победу над ненавистным врагом - фашисткой Германией, желание помочь Красной Армии вдохновляли нас на трудовые подвиги, социалистическое соревнование рождало героев земли, помогало преодолевать трудности. Смогли бы мы добиться успеха, если бы наши тракторы были плохо отремонтированы? Конечно нет. Прежде чем выехать в поле, мы любовно, по-хозяйски отремонтировали каждую машину, наши ремонтники - токарь Иван Сливка, слесарь Василий Черников, электросварщик В. Золотарей, инструментальщик Петр Куценко и другие поработали на славу. Честь и хвала им. Наши тракторы не стояли в борозде, не имели поломок и аварий-

..В будущем году мы обязаны собрать хлеба ещё больше. Что нужно для этого? Надо за зиму так отремонтировать тракторы, сельхозинвентарь, чтобы они с первых же дней весны действовали как часы ) [31].

Несмотря на огромные трудности, сельское хозяйство края работало всё устойчивее. В 1944 году сельские труженики края одержали выдающуюся победу, получив небывалый урожай колосовых в условиях войны, после неурожайного 1943 года. С одного гектара получили по 13,8 
центнеров зерна против 13 ц в 1940 г. Хороший урожай позволил краю сдать государству $37 \mathrm{MлH}$ пудов, почти в три раза больше, чем в 1943 года $[2$, л. 287] Улучшилось продовольственное обеспечение население. Колхозы и совхозы стали получать тракторы, автомобили, запасные части для сельскохозяйственной техники, увеличились поставки в край угля, нефтепродуктов. Немаловажным был морально-психологический фактор связанный с приближением окончания войны. Многие хозяйства работали всё устойчивее, добиваясь высоких результатов. Так, совхоз Темижбекский, сдал государству в 1943 году 2658 т зерна, в 1944 г. 5792 т, в 1945 г. 9182 т [23, с. 200].

Благодаря огромным усилиям и самоотверженности тружеников села в 1945 г. объёмы сельскохозяйственного производства в крае состави- ли две трети по отношению к довоенному уровню $[34$, с. 53,54$]$. Такой разрыв был связан не только с разрушениями оккупантов, но и с тем, что в 1945 г. край постигла жестокая засуха, в результате чего сбор зерновых составил 45 \% к 1940 г. Большие трудности сложились в связи с нехваткой кормов для животноводства, с уменьшением поставок транспорта, топлива, металла, угля и т.д. $[24$, c. 52,53$]$.

Конечно, для окончательного восстановления сельского хозяйства края и выхода его на довоенный уровень было ещё далеко. Но восстановительные работы, проведённые в период войны, заложили прочные основы для быстрейшего восстановления и дальнейшего развития сельского хозяйства Ставрополья.

\section{Источники и литература}

1. Большевистская правда. Г. Будённовск. 1943. 25 марта

2. В суровые годы войны. Ставрополь: Ставропольское книжное издательство, 1978. 352 с

3. Государственный архив новейшей истории Ставропольского края (далее - ГАНИСК). Ф.63. Оп.1. Д.179.

4. ГАНИСК. Ф.63. ОП.1. Д.3.

5. ГАНИСК. Ф.63. ОП.16. Д.16

6. ГАНИСК. Ф.63. Оп.16. Д.208.

7. Государственный архив Ставропольского края (далее - ГАСК). Ф. 1852. ОП. 12. Д.44

8. ГАСК. Ф. 1852. ОП. 12. Д.51.

9. ГАСК. Ф.1852. ОП 7. Д.119.

10. ГАСК. Ф.1852. ОП. 7. Д. 131

11. ГАСК. Ф.1852. ОП.12. Д.50.

12. ГАСК. Фр. 1852. ОП.12. Д.62

13. ГАСК. Фр.1852. Оп.11. Д.65.

14. ГАСК. Фр.1852. Оп.5 Д.65

15. ГАСК. Ф.1852. Оп.5. Д. 5.

16. Колхозная газета. 1943. 20 мая.

17. Коммунистическая партия Советского Союза в резолюциях и решениях съездов, конференций, пленумов ЦК. (1898-1988). Т.6. 1941-1954. Изд. 8-е, доп. и испр. М.: Политиздат, 1971. 815 с.

18. Ованесов Б. Т., Судавцов Н. Д. Здравоохранение Ставрополья (1918-2005 гг.). Ставрополь: ООО Стройиздат-Грантстрой, 2007. 544 с.

19. Российский государственный архив социально-политической истории (далее - РГАСПИ). Ф.17. Оп. 43. Д.1820.

20. РГАСПИ. Ф.17. ОП. 43. Д.507.

21. РГАСПИ. Ф.17. ОП.43. Д.834.

22. Решения партии и правительства по хозяйственным вопросам. В 5-ти т. Т 3. 1917-1967 гг. Сб. документов и материалов за 50 лет. М.: Политиздат, 1968. (1941-1962 гг.). 750 с.

23. Ставрополье в годы Великой Отечественной войны 1941-1945 гг. Сб. документов и материалов. - Ставрополь: Ставропольское книжное издательство, $1962.514 \mathrm{c}$.

24. Ставрополье за 50 лет. Сборник статистических материалов. Ставрополь: Ставропольское книжное издательство, $1968.218 \mathrm{c}$.

25. Ставрополье: правда военных лет. Великая Отечественная война в документах и материалах. Ставрополь: СГУ, 2005. $608 \mathrm{c}$

26. Ставропольская правда. 1943. 10 апреля

27. Ставропольская правда. 1943. 11 мая.

28. Ставропольская правда. 1943. 24 марта

29. Ставропольская правда. 1943. 7 мая.

30. Ставропольская правда. 1944. 1 декабря

31. Ставропольская правда. 1944. 19 ноября

32. Ставропольская правда. 1944. 23 мая.

33. Ставропольская правда. 1944. 5 января

34. Ставропольское село: в людях, фактах, цифрах. Научно-популярное издание. Изд. 2-е доп. Ставрополь: Некоммерческий литературный фонд “Слово и дело», ООО «Блиц-Инфо», 2011. 392 с.

35. Ставропольцы в Великой Отечественной войне. Ставрополь: Ставропольское книжное издательство, 1995. 348 с.

36. Труд. 1944. 27 января. 
1. Bol'shevistskaya pravda. 1943. March 25. (In Russian).

2. V surovye gody vojny (In the harsh war years). Stavropol': Stavropol'skoe knizhnoe izdatel'stvo, 1978. 352 p. (In Russian)

3. State archive of the newest history of Stavropol territory (GANISK). F.63. Inv.1. D.179. (In Russian).

4. GANISK. F.63. Inv.1. D.3. (In Russian).

5. GANISK. F.63. Inv.16. D.16. (In Russian)

6. GANISK. F.63. Inv.16. D.208. (In Russian).

7. State archive of Stavropol krai (GASK). F.1852. Inv.12. D.44. (In Russian).

8. GASK. F.1852. Inv.12. D.51. (In Russian).

9. GASK. F.1852. Inv.7. D.119. (In Russian)

10. GASK. F.1852. Inv.7. D.131. (In Russian)

11. GASK. F.1852. Inv.12. D.50. (In Russian)

12. GASK. Fr. 1852. Inv.12. D.62. (In Russian).

13. GASK. Fr.1852. Inv.11. D.65. (In Russian).

14. GASK. Fr.1852. Inv.5 D.65. (In Russian).

15. GASK. F.1852. Inv.5. D.5. (In Russian).

16. Kolhoznaya gazeta. 1943. May 20. (In Russian).

17. Kommunisticheskaya partiya Sovetskogo Soyuza $v$ rezolyuciyah i resheniyah s»ezdov, konferencij, plenumov CK (The Communist Party of the Soviet Union in resolutions and decisions from, eetings, conferences, plenums of the Central Committee). (1898-1988). Vol.6. 1941-1954. Moscow: Politizdat, 1971. 815 p. (In Russian).

18. Ovanesov B. T., Sudavcov N. D. Zdravoohranenie Stavropol'ya (1918-2005 gg.) (Health care of Stavropol (19182005). Stavropol': OOO Strojizdat-Grantstroj, 2007. 544 p. (In Russian).

19. Russian state archive of social and political history (RGASPI). F.17. Inv. 43. D.1820. (In Russian).

20. RGASPI. F.17. Inv.43. D.507. (In Russian).

21.RGASPI. F.17. Inv.43. D.834. (In Russian).

22. Resheniya partii i pravitel'stva po hozyajstvennym voprosam (Party and Government Decisions on Economic /ssues). In 5 Vols. Vol.3. 1917-1967 gg. (1941-1962 gg.). Collection of documents for 50 years. Moscow: Politizdat, 1968. 750 p. (In Russian).

23. Stavropol'e v gody Velikoj Otechestvennoj vojny 1941-1945 gg. (Stavropol during the Great Patriotic War of 19411945). Collection of documents. Stavropol': Stavropol'skoe knizhnoe izdatel'stvo, 1962. 514 p. (In Russian).

24. Stavropol'e za 50 let. Sbornik statisticheskih materialov (Stavropol over 50 years. Collection of statistical materials) Stavropol': Stavropol'skoe knizhnoe izdatel'stvo, 1968. 218 p. (In Russian).

25. Stavropol'e: pravda voennyh let. Velikaya Otechestvennaya vojna v dokumentah i materialah (Stavropol region: the truth of the war years. World Warll in documents and materials). Stavropol': SSU publ, 2005. 608 p. (In Russian).

26. Stavropol'skaya pravda. 1943. April 10. (In Russian).

27. Stavropol'skaya pravda. 1943. May 11. (In Russian).

28. Stavropol'skaya pravda. 1943. March 24. (In Russian).

29. Stavropol'skaya pravda. 1943. May 7. (In Russian).

30. Stavropol'skaya pravda. 1944. Desember 1. (In Russian).

31. Stavropol'skaya pravda. 1944. November 19. (In Russian)

32. Stavropol'skaya pravda. 1944. May 23. (In Russian).

33. Stavropol'skaya pravda. 1944. January 5. (In Russian).

34. Stavropol'skoe selo: $v$ lyudyah, faktah, cifrah. Nauchno-populyarnoe izdanie (Stavropol village: in people, facts, figures. Popular Science Edition). Stavropol': Slovo i delo, Blic-Info, 2011. 392 p. (In Russian).

35. Stavropol'cy v Velikoj Otechestvennoj vojne (Stavropol in the Great Patriotic War). Stavropol': Stavropol'skoe knizhnoe izdatel'stvo, 1995. 348 p. (In Russian).

36. Trud. 1944. January 27. (In Russian).

\section{Информация об авторе}

Судавцов Николай Дмитриевич - доктор исторических наук, профессор кафедры истории России гуманитарного института Северо-Кавказского федерального университета (Ставрополь) / 249609@mail.ru

\section{Information about the author}

Sudavtsov Nikolay - Doctor of History, Professor, Chair of Russian History, Institute of Humanities, North-Caucasus Federal University (Stavropol) / 249609@mail.ru 